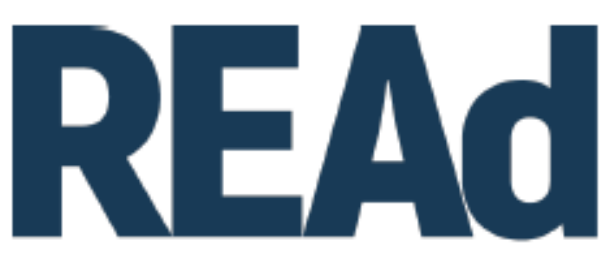

Revista Eletrônica de Administração

\title{
IS IT CROWDSOURCING OR CROWDSENSING? AN ANALYSIS OF HUMAN PARTICIPATION IN DIGITAL PLATFORMS IN THE AGE OF SURVEILLANCE CAPITALISM ${ }^{1}$
}

\author{
Fernando Ressetti Pinheiro Marques Vianna ${ }^{2}$ \\ Francis Kanashiro Meneghetti ${ }^{3}$
}

http://dx.doi.org/10.1590/1413-2311.280.96476

\begin{abstract}
This paper contributes to studies on the dark side of digitization by relying on the concept of surveillance capitalism to analyze the role of individuals in digital organizations in performing activities known as crowdsourcing. Even though there is a discourse of empowerment and mutual interest exchanges between organizations and individuals through crowdsourcing, the transformation of computer systems into the socalled 4.0 era or 4.0 industry seems to have altered their role in digital organizations as well. These individuals began to be analyzed from the data they produce, and no longer from their desires, thus approaching the sensors of these organizations. Using the case study method, we analyze the contents of the Netflix, Facebook and Google platform home pages, as well as their terms of service and privacy policies. The way users participate in these platforms is analyzed, as well as the way their data are exploited, and the reason why this continuous exploitation of data occurs. We argue that this exploration alienates the empowering and participatory concept of crowdsourcing and brings the passive concept of individuals closer together as sensors, or crowdsensing.

\footnotetext{
${ }^{1}$ Recebido em 15/9/2019, aceito em 16/3/2020.

${ }^{2}$ Universidade Federal Tecnológica do Paraná - Programa de Pós-Graduação em Administração; Curitiba - PR (Brasil); https://orcid.org/0000-0002-5698-477X; fvianna2009@hotmail.com

${ }^{3}$ Universidade Federal Tecnológica do Paraná - Programa de Pós-Graduação em Administração; Curitiba

- PR (Brasil); https://orcid.org/0000-0003-0327-2872; fkmeneghetti@gmail.com
} 
This approach, instead of treating individuals as singular, quantifies and categorizes their uniqueness to meet the controlling longings of hegemonic organizational structures, limited by capitalist discourse, or surveillance capitalism.

Keywords: Crowdsourcing. Crowdsensing. Surveillance capitaism. Digital platforms. Dark side of digitalization.

\section{ISSO É CROWDSOURCING OU CROWDSENSING? UMA ANÁLISE DA PARTICIPAÇÃO HUMANA EM PLATAFORMAS DIGITAIS À LUZ DA PERSPECTIVA DO CAPITALISMO DE VIGILÂNCIA}

Esse artigo contribui para estudos sobre o lado obscuro da digitalização, com base no conceito de capitalismo de vigilância para analisar o papel dos indivíduos nas organizações digitais na realização de atividades conhecidas como crowdsourcing. Embora exista um discurso de empoderamento e trocas de interesses mútuos entre organizações e indivíduos por meio do crowdsourcing, a transformação de sistemas de computador nos chamados 4.0 ou Industry 4.0 também parece ter mudado seu papel nas organizações digitais. Essas pessoas começaram a se analisar a partir dos dados que produzem, e não mais de seus desejos, aproximando-se dos sensores dessas organizações. Usando o método de estudo de caso, analisamos o conteúdo das home pages da plataforma Netflix, Facebook e Google, bem como seus termos de serviço e políticas de privacidade. A maneira como os usuários participam dessas plataformas é analisada, bem como a maneira como seus dados são explorados e o motivo dessa exploração contínua de dados. Argumentamos que essa exploração afasta o conceito empoderador e participativo de crowdsourcing e aborda o conceito passivo dos indivíduos como sensores ou detecção coletiva. Essa abordagem, em vez de tratar os indivíduos como singulares, quantifica e classifica sua singularidade para satisfazer os desejos controladores das estruturas organizacionais hegemônicas, limitadas pelo discurso capitalista ou pelo capitalismo de vigilância.

Palavras-chave: Crowdsourcing. Crowdsensing. Capitalismo de vigilância. Plataformas digitais. Dark side da digitalização.

\section{¿ES ESTO CROWDSOURCING O CROWDSENSING? UN ANÁLISIS DE LA PARTICIPACIÓN HUMANA EN PLATAFORMAS DIGITALES A LA LUZ DE LA PERSPECTIVA DEL CAPITALISMO DE VIGILANCIA}


Este artículo contribuye a estudios sobre el lado oscuro de la digitalización, basándose en el concepto de capitalismo de vigilancia para analizar el papel de los individuos en las organizaciones digitales en la realización de actividades conocidas como crowdsourcing. Si bien existe un discurso de empoderamiento e intercambios de intereses mutuos entre organizaciones e individuos a través del crowdsourcing, la transformación de los sistemas informáticos en la llamada era 4.0 o Industria 4.0 también parece haber cambiado su papel en las organizaciones digitales. Estas personas comenzaron a analizarse a partir de los datos que producen, y ya no a partir de sus deseos, acercándose a los sensores de estas organizaciones. Utilizando el método de estudio de caso, analizamos el contenido de las páginas de inicio de la plataforma Netflix, Facebook y Google, así como sus términos de servicio y políticas de privacidad. Se analiza la forma en que los usuarios participan en estas plataformas, así como la forma en que se explotan sus datos y la razón por la que ocurre esta exploración continua de datos. Argumentamos que esta exploración aliena el concepto empoderador y participativo de crowdsourcing y acerca el concepto pasivo a los individuos como sensores, o detección colectiva. Este enfoque, en lugar de tratar a los individuos como singulares, cuantifica y clasifica su singularidad para cumplir con los anhelos controladores de las estructuras organizativas hegemónicas, limitadas por el discurso capitalista o el capitalismo de vigilancia.

Palabras clave: Crowdsourcing. Crowdsensing. Capitalismo de vigilancia. Plataformas digitales. Dark side de digitalización.

\section{INTRODUCTION}

According to Linstead, Maréchal, and Griffin (2014), the dark side theme of organizations deals with the dark side of practices carried out by organizations within their terrain and through their practices and policies. This theme has been explored in Brazil in previous researches, from postcolonialist perspectives and corporate crimes (SILVEIRA and MEDEIROS, 2014), to misbehavior and humor in organizations (DE OLIVEIRA MEDEIROS and ALCADIPANI, 2016) and animal ethics in organizations (BARRETO et al., 2017), among others.

Although there is a history of publications on the dark side of organizations, since digital organizations have been featured in discussions about organizational 
practices, the dark side theme of organizations presents new possibilities for research. Such possibilities are evidenced, outside Brazil, by the special edition of works that explored the dark and unexpected sides of digitization in the year 2019 of the periodical Organization (ORGANIZATION, 2019). In this call, the attention focused on the unexpected side effects of digital organizations' practices on users, employees, and other corporations.

The recent discussion about the dark side of digitization takes place in such areas as false awareness related to the sharing economy (OSSEWAARDE; REIJERS, 2017) and surveillance and monitoring of individuals by organizations (UPCHURCH; GRASSMAN, 2016) on social networks. Beyond the technologies themselves, digital organizations rely on the adoption of innovative tools, the exploration of unexpected sources of income generation, and the perilous heights of Silicon Valley start-ups (ZUBOFF, 2019).

Despite the hegemonic discourse on digitization spectacularization, the way these organizations operate is the focus of critical research. From this presentation, the present paper looks at the dark side of digital organizations from the concept of surveillance capitalism and the participation of individuals connected by the internet in the productive processes of these organizations.

The subject of surveillance capitalism is still recent, given that the term was coined by Zuboff in 2015 (ZUBOFF, 2015), and still requires structuring within organizational studies. The author states that surveillance capitalism can be analyzed as a new market that relies on intense vigilance to achieve profit. This surveillance occurs not only through the participation of users of digital platforms and applications, but mainly from behavioral surplus, or behaviors that exceed the integration activity between the individual and the machine (ZUBOFF, 2019). These behaviors generate data that are harnessed in different ways by capitalist organizations.

The integration activity between individuals on machines, through digital platforms and applications, is called, among other names, crowdsourcing (HOWE, 2006), and designates the participation or collaboration of a crowd in generating collective intelligence. The precursor literature on the subject looks at this relationship as a way to empower the individual and allow everyone to be heard (HOWE, 2006; O'REILLY, 2009). However, this participation or collaboration generates a surplus that has been expropriated by digital organizations to accumulate and process as much data as possible (ZUBOFF, 2019). 
Data, according to the World Economic Forum (WEF, 2019), is the oil of contemporary production processes, and the so-called Industry 4.0, which involves numerous other terms such as the Internet of Things, Big Data, and Smart things (COULDRY; MEJÍAS, 2019). These terms give the impression that the digital world is much safer and more sophisticated (PASQUALE, 2015).

Despite the apparent security of the digital world and the apparent empowerment generated by crowdsourcing for individuals, when such concepts are analyzed in the light of surveillance capitalism, it is noticeable that digital organizations are only interested in the generated data. Thus, when the focus of digitization ceases to be the individual and his demands and becomes the data produced, individuals are observed as machine sensors or industrial sensors and generate a model of individual-organization relationship called crowdsensing (CONTI; PASSARELLA; DAS, 2017; DAWID et al., 2017).

In the present study, organizations such as Google, Netflix, and Facebook, which have fully digitized processes (LIN et al., 2018; PILLONI, 2018) and which are developed from Information and Communication Technologies (ICT), expanding every second, their storage capacity and data analysis (DAWID et al., 2017) are observed from a tension between crowdsourcing discourse and crowdsensing practice.

The expansion of digital data storage and analysis capacity by digital organizations is primarily due to the US government's interest in mapping and monitoring the world and its individuals in the post-September 11 era (KUMAR, 2017; COULDRY, 2017). Consequently, this surveillance required organizations capable of expropriating and processing the data of individuals to meet the wishes of the state. In this way, organizations with this capacity began to adopt the surveillance capitalism framework model, with the justification of serving the interests of the state. These relations between state and private organizations have resulted in a capitalist structure in which organizations themselves guide permissive policies and laws that support surveillance to achieve increasingly significant financial results (KUMAR, 2017; COULDRY; MEJÍAS, 2019).

In this era of surveillance capitalism, individuals are treated exclusively as data producers, including in their relations with the state and with laws (ZUBOFF, 2019). Furthermore, all data related to individuals' movements and their interaction with the virtual world are now collected, whether voluntarily or not, by digital organizations, in a process of datafication (MAYER-SCHÖNBERGER; CUKIER, 2014). These data, (1) (1) REAd | Porto Alegre - Vol. 26 - N..$^{\circ} 1$ - Janeiro / Abril 2020 - 176-209. 
according to O'Neil (2016), are used intensively, to the point of exhaustion, to map the weaknesses, emotions, and memories of individuals, with the goal of organizations taking advantage of this to achieve financial results.

To structure the discussions about the subject of surveillance capitalism and its operationalization based on activities that fall between crowdsourcing and crowdsensing, the present study is outlined through the case study method. This case study is developed by analyzing how individuals participate in three digital platforms, and why this participation is important for the operation of the surveillance capitalism model applied on these platforms. To this end, we analyzed the Netflix, Facebook and Google platforms, their main pages, privacy policies and terms of service, as well as secondary articles on the structure and operation of the platforms.

The article presents a theoretical framework on surveillance capitalism, directed, in its structural aspects, to the analysis of the participation of users of the platforms in question. This is followed by the concepts and structures of crowdsourcing, such as the type of activities and motivational factors involved, up to the model currently used, crowdsensing. The paper then analyzes the three digital organizations and the ways users participate in these organizations in light of the concepts of crowdsourcing and crowdsensing, followed by an analysis of this participation through the lens of surveillance capitalism. Finally, the paper presents a discussion of the results the conclusions.

\section{THE SURVEILLANCE CAPITALISM PERSPECTIVE IN THE ANALYSIS OF THE CROWDSOURCING-CROWDSENSING PHENOMENON}

At the beginning of his seminal book, in which he coined the term surveillance capitalism, Zuboff (2019) presented the case of the development of a system that could be the smart home principle. This system was developed by Georgia Tech researchers in the year 2000 and functioned as a closed system that collected data from sensors scattered in appliances and stored them. The goal the researchers envisioned was for this system to direct their efforts to interpret the data collected to improve the lives of families or people living in the home.

The case of the Georgia Tech researchers' smart home, presented by Zuboff (2019), was neither the first nor the last time that efforts or activities relying on data capture and analysis were developed and justified from altruistic discourses. The case of 
the use of so-called affective computing to assist the treatment of autistic children, by El Kaliouby, Picard and Baron-Cohen (2006), was also mentioned by Zuboff (2019) as an initially positive case, but was later absorbed by contemporary organizations as part of the surveillance capitalism ploy.

In both cases presented, and in numerous others already known in the Big Data and Surveillance Capitalism literature, the researchers presented the results or products that would be delivered from the study as positive for the individuals or groups involved. In the case of affective computing (EL KALIOUBY, PICARD; BARONCOHEN, 2006), health would benefit, and in the case of the smart home (KID et al., 1999), families and the relationship with their homes. However, according to Zuboff (2019), on a later occasion after the publication of the initial research, the products of these studies were either negotiated with profit-seeking business organizations or patented by profit-oriented companies through surveillance activities.

As a product is the result of a productive process involving raw material and competitive priorities, with these priorities driving such a process, Zuboff (2019, p. 14) stated that "the raw material of surveillance capitalism is data, and competing priorities are defined by the organizations that assume ownership of the data".

The importance of data in the contemporary world was evidenced in the 2019 World Economic Forum report (WEF 2019, p. 4), in which data appeared as "the new oil," and data scientists appeared as workers. capable of "extracting it (data), refining and deploying this new source of value in the global economy." The same WEF report stated that data and information science will improve the delivery of private and public services and that the world needs to prepare its workforce for such a reality. However, no results were found in a search for the word "privacy" in the same report.

The concern over privacy lies in the fact that the data come, in the words of Zuboff (2019), from behavioral surplus. The behavioral surplus is the surplus of our behavior when we interact with digital things or the so-called Internet of Things, and it generates a social quantification model from our interaction with cell phones, vehicles and thermostat devices, among others (ZUBOFF, 2019; COULDRY; MEJÍAS, 2019). Zuboff (2019) and Couldry and Mejías (2019) claimed that surveillance capitalism reverses the flow of data usage in business. This means that rather than directing data to actions that address consumer or user demands, data are used to anticipate the consumer's choices and direct them according to the interests of those who own the data. 
In their discourse, organizations that use surveillance capitalism as the basis of their business claim that exploiting or grouping data from behavioral surplus does not affect individuals (SAHDE; SINGH, 2016; COULDRY; YU, 2018). This discourse, while presenting rational elements and being aesthetically pleasing, may have other intentions (COOPER; BURREL, 1988).

The rationality applied to justify data expropriation is given by different arguments, but its beginning was based on fear. According to Foster and MacChesney (2014), maintaining a permanently war-torn state in which the United States has lived since the end of World War II involved government efforts with researchers, universities, businesses and the media, and resulted in the development of military solutions, including surveillance. Foster and MacChesney (2014) and Sahde and Singh (2016) stated that since the September 11 attacks there has been an increase in the number of companies developing technologies for home and digital monitoring and surveillance, with the formal goal of counteracting terrorism. The emergency demand for a state of war means that those who oppose such a state of war and those who oppose capitalism are considered enemies (FOSTER; MACCHESNEY, 2014).

It is clear, then, that the key point of surveillance capitalism lies in common ground between the discourse of security and the expropriation of data from behavioral surplus. For Kumar (2017), this congruence is exposed in two US National Security Agency surveillance programs launched and scaled up from the early 2000s. The first program involves the collection of metadata from domestic telephone data, the USA Patriot Act, and the second, known as the Foreign Intelligence Surveillance Act (FISA), involves collecting communication data from people located outside the United States (PCLOB, 2014).

Such programs, according to Kumar (2017), act as a legal device for the US government to use data captured by companies such as Google, Facebook, Yahoo, Microsoft, YouTube, AOL, Apple, and Skype for surveillance of email and phones in the name of security. At the same time, the purpose of organizations that collect data is not to pass them on to the government, but to achieve one of what they are looking for. The goal of such organizations, according to WEF (2019) and Mayer-Schömberger and Cukier (2013) themselves, is datafication, i.e., data processing and their transformation into a product (ZUBOFF, 2019), which is predictive information.

Initially, according to Zuboff (2019), platforms like Google and Facebook seemed to cater to what web users demanded, which was information, the enhancement 
of their social relationships, and even some empowerment in the face of a new digital world. However, the possibility of relying on any perceptions of individuals, whether consciously or not, to achieve their investors' emergency financial results, and organizational hegemony has transformed the logic of the digital business world (ZUBOFF, 2019). For Mozorov (2013) and Silvermann (2017), the digital business model we know today centralizes endless amounts of data and is based on advertising based on location, memories, and feelings.

Zuboff (2019) stated that the current digital business model operates under the prerogatives of surveillance capitalism, and the fact that there is no precedent for this data expropriation behavior leaves the terrain of this business model unshaken. The perception of the unwavering business model is justified by Google's chief economist Hal Varian when he says that users themselves are seeking greater certainty in their search, and this makes these same users of digital platforms want their information to be in the networks (VARIAN, 2014). Such information, according to Benkler (2000) and Charitsis, Zwick, and Bradshaw (2018), is used in the structure of surveillance capitalism as a bait, which when consumed by the user will inevitably have its behavioral surpluses expropriated by organizations.

For O’Neil (2016), Couldry (2017) and Eubanks (2018), surveillance capitalism's infrastructure depends on connectivity, which also generates decision automation. These are decisions that are made by so-called algorithms from a large amount of data or Big Data that can cause problems related to social policies, increase and maintenance of inequality and invasion of privacy (O'NEIL, 2016; COULDRY; MEJIAS, 2019); and yet users are not aware of these consequences.

The lack of users' perception of the real consequences of this connectivity, coupled with surveillance capitalism occurs, according to Zuboff (2019), because the data expropriation procedure takes place through the installation of imperceptible cookies on our devices, even when we turn them off. Altaweel, Good and Hoofnagle (2015) explained that a cookie is a message that a web browser stores when a website is visited. The authors also stated that websites and digital platforms often use cookies to track visits to the same site or different sites and platforms, and are not perceived by the user, which justifies their free traffic on technology devices.

Authorization for these cookies to be installed on technological devices is given through the terms of services, which are those terms that provide standardized information about the operation of software and applications (VENTURINI et al., 
2016). For Venturini et al. (2016) and Zuboff (2019) these terms are unilaterally defined and presented as a condition sine qua non for the proper functioning of the systems, and in many cases are composed of hundreds or thousands of pages and terms.

Reading and compliance with the terms of service are virtually automatic, and a dead-end, as safety and operation is only guaranteed by the supplier through acceptance (VENTURINI et al., 2016; ZUBOFF, 2019). In a study conducted in 2018, Obar and Oeldorf-Hirsch (2018) analyzed more than five hundred responses from online service and application users and found that $74 \%$ skip acceptance via the quick accept button, and $97 \%$ do a thirty-second reading of contracts that would take at least 15 minutes to read.

Despite the elements presented, which relate expropriation and data analysis to the concept of surveillance capitalism, there is a discourse that treats these participations (or expropriations) of individuals as voluntary and beneficial. This discourse is based on the concept of crowdsourcing and presents user-generated data as a form of empowerment or co-creation of what is delivered as a product to individuals. However, the discussion on crowdsourcing allows an approach from individuals as sensors, presented in this paper as an interrogation or criticism (HELLER; FEHÉR, 1998) to the hegemonic concept regarding the functioning of collective intelligence platforms.

From the analysis of the concepts and elements of surveillance capitalism explored so far, this study goes on to present the path taken from crowdsourcing to crowdsensing.

\section{FROM CROWDSOURCING TO CROWDSENSING}

\subsection{CROWDSOURCING}

Crowdsourcing is not exactly new, even with authors such as Schenk and Guittard (2011) and Howe (2006) assigning the term to a combination of crowd and outsourcing constructs. According to Afuah and Tucci (2012), in 1714 the British government already made use of awards in exchange for scientific collaborations, with the Longitudinal Prize, aimed at the development of a tool that would determine the positioning of ships. However, what makes crowdsourcing an important ally of organizations like Netflix, Google and Uber is the union between a connected crowd and the so-called web 2.0 (O'REILLY, 2007). 
According to Treddinick (2006) and Berthon et al. (2012), the possibility of having a more powerful version of the web (web 2.0) enabled a new level of information flow between users and companies. According to Schenk and Guittard (2011) and Penin and Burger-Helmchen (2011), crowdsourcing has come to be seen by organizations as a way to innovate and seek solutions to their difficulties through open calls and recruitment that are much broader than their own, beyond the boundaries of the organization.

The term is commonplace when related to so-called collective intelligence (LAUBACHER, 2012; MALONE; LAUBACHER; DELLAROCAS, 2010; SELTZER; MAHMOUDI, 2012), and is made possible by systems that rely on the efforts of a broad group of globally connected individuals, producing produces data and information voluntarily or not. The idea of crowdsourcing was that connected individuals could mean better results for the organization than an internal R\&D sector. This idea is based on accounts such as the observation made by Francis Galton in 1907, in which Galton observed at a fair a group of 787 people who, on average, came closer to the correct result of the weight of a piece of meat than the individual opinion of each person (PONSONBY; MATTINGLY, 2015).

The concept of individuals actively participating in the production process, defining colors of goods, vehicle modules or tennis models, was named by Tofler as prosumers (TOFFLER, 1980), but studies on crowdsourcing have broadened their scope over time regarding this kind of participation. When he coined the term in 2006 (HOWE, 2006), Jeff Howe aimed, innocently or not, at the opportunities this form of activity would lead to amateur individuals who could enjoy pecuniary returns from their pastimes. The author presented the case of the IStockPhotos photo bank, the Threadless T-shirt design platform, and a television station that featured amateur videos to put together its programming.

The romantic vision of crowdsourcing presented by Howe (2006) started a series of articles that began to analyze the factors of the so-called "genome of collective intelligence" (MALONE; LAUBACHER; DELLAROCAS, 2010), composed of questions such as: Why individuals participate in crowdsourcing; what is done in crowdsourcing; who performs the activities; and how the activities are performed. Thus, different articles sought to understand the motivational factors related to the participation of individuals in crowdsourcing (ZHENG; LI HOU, 2011; SOLIMAN; TUUNAINEN, 2015; ZHAO; ZHU, 2014; CUPIDO; OPHOFF, 2014; AITAMURTO, 
2015; ZOLKEPLI et al., 2015; AL SUKAINI, ZHANG; ALBAZOONI, 2015) and the types of activities performed by these individuals (SCHENK; GUITTARD, 2011; SCHUURMAN et al., 2012; GOOD; SU, 2013; MAJCHRZAK; MALHOTRA, 2013; SAXTON, OH; KISHORE, 2013; NAKATSU, GROSSMAN; IACOVOU, 2014; HOSSAIN; KAURANEN, 2015; PRPIC; TAEIHAGH; MELTON, 2015; SIVULA; KANTOLA, 2015; FABER; MATTHES, 2016).

These articles explored the motivational factors that could impact an individual's participation in an activity such as rating a service, called crowdevaluation (SIVULA; KANTOLA, 2015) and the crowd rating system (FABER; MATTHES, 2016), or participate in a service, an activity that would involve innovating some aspect of a product or service, called crowdsourcing for innovation challenges (MAJCHRZAK; MALHOTRA, 2013), crowdsourcing of complex tasks (SCHENK; GUITTARD, 2011) and idea generation (HOSSAIN; KAURANEN, 2015).

As for the motivational factors involved in crowdsourcing activities, the creators of the collective intelligence genome narrowed it down to three possibilities: love, money, and glory (MALONE; LAUBACHER; DELLAROCAS, 2010). However, other authors cited other factors such as skills development (BRETSCHNEIDER; LEIMEISTER; MATHIASSEN, 2014; VASANTHA et al., 2014; HOSSEINI et al., 2015; TRAN; PARK, 2015); ENTERTAINMENT (ANTHUAN; SHOOAIB; JOOYOUNG, 2012; VASANTHA et al., 2014; ZOLKEPLI; HASNO; MUKHIAR, 2015; TRAN; PARK, 2015); and socialization (ANTHUAN; SHOOAIB; JOOYOUNG, 2012; VASANTHA et al., 2014; TRAN; PARK, 2015).

As for the goals of crowdsourcing platforms and websites, since their inception, there have been numerous interests to be met by different organizations and through different avenues. It can be stated that from simple activities such as providing geographical location, as done by platforms such as Google Earth (COLEMAN; GEORGIADOU; LABONTE, 2009) and Crisiscommons (ZOOK et al., 2010), to solving complex projects, such as searching for sites that could be gold mines for a large corporation such as GoldCorp (BLOHM; LEIMEISTER; KRCMAR, 2013), or selecting from a variety of chemical, safety or pharmaceutical projects on the Innocentive platform (KHASRAGHI; TAROKH, 2012) are crowdsourcing projects.

With so many possibilities, more recent articles in the field has come to name organizations or platforms as crowdsourcers, and solvers as crowdsourcees (ZOGAJ; BRETSCHNEIDER; LEIMEISTER, 2014). Thus, it is possible to observe a division or 
professionalization in what Howe (2006) initially saw as an enjoyment of the amateur effort due to the more powerful internet, web 2.0 (TREDINNIK, 2006; O'REILLY, 2007). However, this professionalization was not generated by individuals or crowdsourcees, but by the organizations themselves, or crowdsourcers, who identified a cheap and efficient workforce in this connected crowd.

If initially Howe (2006) and O'Reilly (207) saw standardizing blogging interfaces and social networks as a way of empowering individuals and bringing meaning to connected activities, the goods and services industries are now looking at crowdsourcing as an ability to reduce costs and improve their productive and commercial performance (PAPANASTASIOU; BIMPIKIS; SAVVA, 2017). Thus, capturing, storing and crossing as much data as possible, or, in the case of organizations that exploit the so-called ICTs, data commodities (FUCHS, 2011) has become an emergency. This is because a simple color change in a product's packaging affects millions of purchases (O’NEIL, 2016). This is what McLuhan and Nevitt (1972) warned as an era of simultaneity that overlapped sequentiality.

The adoption of rankings, categories and virtual awards removes amateurism and imposes professional methods of ensuring involvement and results for the organization. However, when faced with a society totally immersed in their digital devices, organizations realize that not only the willingness of volunteers their processes can depend. In this way, new models of expropriation of data are adopted with the objective of reaching all types of activities of the connected individuals, and who act under conscious and unconscious prerogatives regarding the individual's action (ZUBOFF, 2019).

So, would it be possible to maintain the term crowdsourcing for unconscious work activities? Activities such as an assessment that is carried out by the individual in order to return a good or bad experience to the provider, but which ends up working as a raw material for future decisions on a digital platform, and not always reaching the provider, can be named as crowdsourcing?

\subsection{CROWDSENSING}

With the advent of a goods and services industry that increasingly relies on a combination of new technologies and knowledge management from its external 
environment (AHLSKOG; BRUCH; JACKSON, 2017), new terms have come to dominate the entire environment of organizations.

Terms such as 4.0 and digitization have come to occupy a prominent place in projects in industrialized countries. Different terms are used by different nations to identify projects that have the same goals: the optimization of production processes beyond the processes themselves (LIN et al., 2018; PILLONI, 2018). To designate these projects, developed countries rely on modern and aesthetic terms such as Industry 4.0 in Germany (YIN, STECKE; LIN, 2017; MORAR; ARMAN; MOUSA, 2017); the 5.0 society in Japan (YIN, STECKE; LIN, 2017); the industrial internet in the United States (BURMEISTER; LUTTGENS; PILLER, 2016; PILLONI, 2018); Industrie du Futur in France (ABRAMOWICZ; AUER; HEATH, 2016); and Chinese Manufacturing +2025 (YIN, STECKE; LIN, 2017; PILLONI, 2018). To Lin et al. (2018) and Pilloni (2018), all the projects mentioned are related to the development of new forms of technologies concerning data capture, cyber systems, the Internet of Things (IoT), Big Data and cloud computing.

However, the new industrial processes are not only composed of cybernetic and IoT systems. Other terms are often used to define this contemporary model of processes, such as intelligent production systems (MORAR; ARMAN; MOUSA, 2017; LIN et al., 2018), intelligent and digital manufacturing (QIN et al., 2016; MALACUKZI, 2017), big data (YAO; LIN, 2016; PILLONI, 2018; YANG; SHEN; WANG, 2018), mass customization (YAO; LIN, 2016; DING; JIANG; SU, 2018), cyber-physical system (CPS) (SONG; MOON, 2016; CAGGIANO, 2018) and 3D printing (DAWID et al., 2017; BAUMANN; ROLLER, 2017).

All the terms mentioned above are part of a large internet-connected production system that is directed towards a variety of goals, such as product development (MORAR; ARMAN; MOUSA, 2017; YANG, SHEN; WANG, 2018), innovation (LEE; BAGHERI; JIN, 2016; YAO et al., 2017; LI et al., 2018), and problem solution (ZHANG et al., 2017; ZENAIB; ELMUSTAFA, 2017; HASSAN et al., 2018). However, to achieve all these objectives, there is a reliance on data as the main raw material (GAO et al., 2015). Thus, the attention of organizations that depend on this data to have their systems fully functioning is focused on capturing large volumes of data that enable virtual environments and intelligent products and services (DAWID et al., 2017). 
To achieve their goals, organizations seek to expand their ability to store data on individuals, ranging from data on physical and financial movements to likes and habits on social networks (JACKSON, 2016; O’NEIL, 2016). This constant vigilance generates petabytes of information regarding human behavior (O'NEIL, 2016). Thus, it can be said that individuals are no longer active in their participation in virtual activities, but passive in stimulating social networks, acting as sensors that react to what pleases, dislikes, and arouses desire or repulsion. Some authors have named this new crowdsourcing model crowdsensing (SHU et al., 2017; DAWID et al., 2017; ZENAIB; ELMUSTAFA， 2017; CONTI; PASSARELLA; DAS ， 2017; VALERIO; PASSARELLA; CONTI, 2017; CAGGIANO 2018; HASSAN et al., 2018).

Although authors such as Hassan et al. (2018) and Caggiano (2018) restrict crowdsensing to capturing data from machines and equipment in one industry, and for greater efficiency, other authors are direct about the purpose of crowdsensing in other areas. Conti, Passarella, and Das (2017) and Dawid et al. (2017) stated that crowdsensing is a form or tool that centralizes for a receiving system a large amount of data produced by individuals connected through their mobile devices to impact the management of physical systems and generate intelligent environments and products.

This large amount of data that allows organizations to quantify perceptions and meanings is called datafication (SHILTON, 2010; LEHTINIEMI, 2017), and creates a vicious circle in organizations that today increasingly rely on this type of tool. Valerio, Passarella, and Conti (2017) reported that production processes are continuously reconfigured from the collected data. These reconfigurations are responsible for ensuring increasingly important results for organizations, regardless of the impacts generated on the internal and external environment (O’NEIL, 2016). The monetization of behavior now justifies the institutionalization of any kind of surveillance (ZUBOFF, 2015), and completely abandons Howe's (2006) romantic view.

In this way, would it be possible to affirm that a new moment in the relationship between individuals and digital organizations ends up establishing itself, at least in relation to the contributions of the former in meeting the demands of the latter? And how this relationship is established, considering that, based on the concept of crowdsensing, the search (crowdsourcer) is no longer necessary, as the simple act of the individual interacting with a digital device already ensures that their data reaches the organization. 


\section{METHOD}

This study uses the case study method, based on the approach of Yin (2017), and intending to establish a discussion structure on a recent theme. To achieve this goal, the author states that the case study method can be developed from the "how" and "why" questions, and further suggests that "The case study is an investigation of a contemporary phenomenon within its real-life context, especially when the boundaries between the phenomenon and the context are not clearly defined" (YIN, 2017, p. 32).

To carry out this investigation, we will follow the author's instructions, answering the questions: how do individuals participate in digital platforms from the concepts of crowdsourcing and crowdsensing, and how are these participations conditioned through their terms of service; and "why" do the studied digital platforms need these participations to take ownership of user data and make their business viable?

This discussion framework was established from an analysis of three different digital platforms: Netflix, Facebook, and Google, which present the participation of individuals as a form of crowdsourcing. However, the same participations can be presented considering the concept of crowdsensing and thus approach the expropriation of data that enable surveillance capitalism.

Therefore, for this case study, a decision was made to analyze the contents of digital platforms, their presentation pages, privacy policies and/or data usage terms of service, their rules, policies and other articles analyzed secondarily.

Initially, the platform is described and then the perspective of user participation in the light of crowdsourcing and crowdsensing is presented. Subsequently, in each case, user participation is analyzed in the light of the surveillance capitalism concept, to clarify the reason for this participation in the platform's operation.

The purpose of this analysis is to verify whether the practices of these digital platforms/organizations are intended for the empowerment of users or the exclusive interest of organizations in the digital world. In the latter case, individuals would be viewed by digital organizations as data producers through connected electronic devices, closer to the concept of crowdsensing (CONTI; PASSARELLA; DAS , 2017; DAWID et al., 2017) and surveillance capitalism. (ZUBOFF, 2019).

Netflix

The Netflix platform is known worldwide for being a breakthrough in the internet television mode (GOMEZ-URIBE; HUNT, 2015). On this platform subscribers, 
who were hitherto limited to video rental, can watch movies and series at any time. Gomez-Uribe and Hunt (2015) also identified the recommendation system as an important innovation, through which the subscriber evaluates the films he has watched and will be shown a menu that is closer to his tastes more effectively and efficiently. These innovations, according to the platform's policies, are continuously tested on user interactions through the interface (NETFLIX, 2019).

The way individuals participate in the Netflix platform can be presented from the empowering action of crowdsourcing (HOWE, 2006; O'REILY, 2006), which makes the subject an evaluator. Crowdsourcing theory names this practice as crowdevaluation (SIVULA; KANTOLA, 2015) and the consumer report model (Saxton, Oh, and Kishore, 2013). According to Sivula and Kantola (2015) and Saxton, Oh and Kishore (2013), this is an activity that may or may not be rewarded monetarily or materially and is usually done in the individual's self-interest.

According to Conti, Passarella, and Das (2017) and Dawid et al. (2017), the evaluative way users participate can also be observed in the light of crowdsensing. For the authors, the data are processed by an algorithm that centralizes them and performs numerous crossovers that generate classifications related to subscribers' movie and series consumption habits. It is a process model that moves away from the romantic view of service personalization to work exclusively based on datafication (SHILTON, 2010; LEHTINIEMI, 2017).

In the case of the Netflix platform, it can be said that the automation generated by an algorithm becomes responsible for defining what the user will prefer, through suggestions and content restrictions (COULDRY; MEJIAS, 2019). This algorithmic and automated system has a privacy policy that even allows users to be tested as sensors in a factory without reacting to such practices (VENTURINI et al., 2016; ZUBOFF, 2019).

Thus, the importance attached to individuals does not focus on their likes, desires, or memories of movies and moments, but rather on the data generated by their behaviors in the face of automated testing and suggestion, in keeping with the concept of behavioral surplus (ZUBOFF, 2019). According to Zuboff (2019) and Pasquale (2015), this behavioral surplus is captured and rendered by the platform algorithm, which generates information and classifications that, in many cases, not even the platform itself controls due to its functioning. A real black box.

Regarding the Netflix platform algorithm, it is important to note that it was developed through the Netflix Prize, a crowdsourcing challenge that awarded the (c) $(1)(2) \operatorname{REAd} \mid$ Porto Alegre - Vol. 26 - N. ${ }^{\circ} 1$ - Janeiro / Abril 2020 - 176-209. 
winners \$ 1 million (BELL; KOREN, 2007). Crowdsourcing challenges (MAJCHRZAK; MALHOTRA, 2013; NAKATSU; GROSSMAN; IACOVOU, 2014) or complex tasks (SCHENK; GUITTARD, 2011) are usually monetarily rewarded and performed by a specialized group of individuals. In the case of the Netflix Prize, Hallinan and Striphas (2014) stated that the algorithm culture was established, given that the forums that featured a debate on the challenge themselves were rendered by algorithms developed by the challenge participants to present the best possible solution.

According to employees of the platform itself, in this new algorithm model, the scale rating system (one to five stars) was set aside to analyze much larger factors, such as film genre and film choice time. (GOMEZ-URIBE; HUNT, 2015). In possession of such data, tests are performed with users to improve the process of targeting and determining what a user might watch.

Facebook

The Facebook social network is known worldwide as the largest social network on the planet, and it works without necessarily having a monetary exchange between its owners and users (RITZER; JURGENSON, 2010). The way users participate is through an avatar, and each member of the social network is differentiated through what they build in that virtual environment. The empowerment suggested by the creators of the social network themselves (THE SOCIAL NETWORK, 2010) is that users can define who will see what they publish in a stratified world.

In the case of the Facebook platform, its empowering crowdsourcing action is related to open collaboration (PRPIC, TAEIHAGH AND MELTON, 2015) and users' content development capacity (HOSSAIN; KAURANEN, 2015). As for the motivational factor involved in the participation of individuals in this type of activity with Facebook, Anthuan, Shoaib and Jooyoung (2012) and Tran and Park (2015) specifically cited pleasure or fun.

As for how users participate on Facebook, from a crowdsensing perspective, Pasquale (2015), Salloum, Al-Emram and Shaalan (2017) and Zuboff (2019) suggested that the product of participation and interactions between intermediated users on the platform are the data used as a source of lexical, semantic and syntactic categories. According to Jackson (2016), O’Neil (2016) and Zuboff (2019), users' actions are no longer considered as producing self-interested content but are now perceived as classifiable and capable data sources to be rendered. Charistsis, Zwick, and Bradshaw 
(2018) stated that user complexity is reduced to sensors and data, which are abstracted by algorithms and transformed into derivatives.

The Facebook user perception of tensions between crowdsourcing and crowdsensing generates an important approximation with the concept of surveillance capitalism. This is because information and categorization derived from user fun data are exploited according to the platform's objective, be it financial or political (WILLIAMS; GULATI, 2013; SALLOUM, AL-EMRAM; SHAALAN, 2017). Although the motivational factor involved in the interaction between Facebook and users is far from financial, Turner (2018) claimed that online intermediation promoted by Facebook would not be between users, but between users and the search for profit by the platform itself.

The fact that motivational factors such as fun are suggested, for example, only corroborates users' lack of perception regarding what happens during the process of the expropriation of their behavioral surplus (ZUBOFF, 2019) and monetization of this surplus. To Venturini et al. (2016), it is possible to show that users may not even be aware of the privacy policies with which they agree, even without actively agreeing, in which it is clear that "what you post, at the moment you submit, is no longer yours, but Facebook's.” (O’NEIL, 2016, p. 179).

In the case of Facebook, privacy policies make it clear that all data and information on users, their interactions with other users or the platform's services and third party users are collected for use by the platform. (FACEBOOK, 2019). These data refer to the production of videos, photos, comments, and interactions, as well as comments and interactions via likes (RITZER; JURGENSON, 2010). These are policies that are permissively based on the state of vigilance and fear after September 11 (FOSTER; MACCHESNEY, 2014; SAHDE; SINGH, 2016; KUMAR, 2017).

Google

The Google platform is a much larger organization than simply an organizer of accessible and useful information for all, as its mission states (GOOGLE, 2019). Its ability to reach individuals in parts of the world, especially in the south of the globe, which would not usually be reached by traditional recruitment from northern organizations, makes Google a key piece of crowdsourcing (ETTLINGER, 2016). This ability to reach, coupled with the complexity of integrated and connected tools such as Google Forms, Google Docs, and Google Maps (GOOGLE, 2019), which make users deposit all their data and their relationships (searches, studies, curiosities, etc.) in the 
same organization, make Google the translation of Big Data rather than a search engine (LINDOO, 2009; MOREL; ALVES; CADET, 2011; O’NEIL, 2016).

This big data is made possible by different crowdsourcing levels performed through the Google platform: consciously, when the user adds an image or evaluates a route in Google Maps (RITZER; JURGENSON, 2010); and unconsciously, when the user searches Google for something (O’NEIL, 2016) and their data are stored by the platform or when their GPS is used to define route suggestions for other users.

As for the types of crowdsourcing involved, both Google Earth and Google Maps use content development when users insert images, for example (COLEMAN; GEORGIADOU; LABONTE, 2009), but also crowdevaluation (SIVULA; KANTOLA, 2015 ) or the consumer report model (SAXTON; OH; KISHORE, 2013) when users evaluate the routes suggested by the platform. Among the motivational factors involved in the participation of individuals who collaborate with the voluntary insertion of information into Google Earth, for example, Coleman, Georgiadou, and Labonte (2009) cited love for the community.

For O'Neil (2016), in the case of Google's search platform, the search action itself has become an important weapon in Google's networks, as involuntary crowdsourcing (SELTZER; MAHMOUDI, 2012). In this model, it is possible to direct the analysis to the concept of crowdsensing, because the individual who seeks information does not want to collaborate, but the data from his research are used as raw material by the organization (JACKSON, 2016).

The perception that we produce raw material for Google is because any search on Google and the action resulting from this search, such as clicking or not clicking on a result, is exploited by the platform to target ads or to influence their subsequent actions (LEHTINIEMI, 2017). These actions with Google are the baits contained in the surveillance capitalism framework, interested in quantifying and transforming user behavior into data (BENKLER, 2000; MAYER-SCHÖMBERGER; CUKIER, 2013; CHARITSIS; ZWICK; BRADSHAW, 2018). According to Zuboff (2019), it is the expropriation of behavioral surplus and its analysis by algorithms. This analysis then generates the information that the platform sells to its customers in the form of suggesting a discount to one individual, a higher price to another, whether or not to authorize funding for a third party or to evaluate an action as criminal or suspicious (PASQUALE, 2016; O’NEIL, 2016; EUBANKS, 2018). 
To gain access to all user data, Google's privacy policy assumes that an individual accepts, when searching for information on Google Search or using Gmail email, that their emails and searches are reviewed for future customizations (VENTURINI et al., 2016). These analyses occur through cookies, which send the user's browsing information to Google and its partners (ALTAWEEL; GOOD; HOOFNAGLE, 2015; ZUBOFF, 2019).

Expropriation of data is intended to improve Google's financial results, which use the most personal information and exploit the vulnerability identified by individual searches (O’NEIL, 2016; LEHTINIEMI, 2017). O'Neil (2016) claimed that to ensure the organization's financial results, Google exploits user search data and presents results to users in an unethical manner. In cases cited by the same author, the results presented are based on the personal, emotional and professional weaknesses identified in the searches, which are already explored in the presentation of the results.

\section{IS IT CROWDSOURCING OR CROWDSENSING?}

According to Silverman (2017), there is a discourse of defense of individual freedom through the possibility of expressing ourselves in social networks and having access to a large amount of information, which masks the strangulation of privacy. This discourse is quite coherent in neoliberalism and modernism since it rationally justifies that data are produced for an extension of the law. However, the postmodern view shows us that this is a ruse of discourse since we are merely data producers and sensors within a capitalist system.

Despite the individuality built by each individual, digital organizations use the capitalist discourse to justify the quantification and categorization of the perceptions, feelings, curiosities, and actions of individuals through technological apparatuses (O'NEIL, 2016). This situation was identified by Wiener (1988) when the author stated that the adoption of computerized technologies and systems is not intended to improve the life of the worker or the community in general but to ensure increased efficiency.

This increase in the efficiency of organizations from voluntary or non-voluntary collaboration occurs in the digital world through crowdsourcing (HOSSAIN; KAURANEN, 2015). If the initial idea of crowdsourcing, as defined by Howe (2006), Schek and Guittard (2011) and Pénin and Burger-Helmchen (2011), is considered as an open call or comprehensive web recruitment, an individual's action would be intrinsic 
towards participation in the activity that generates crowdsourcing. On the other hand, Laubacher (2012), Malone, Laubacher and Dellarocas (2010) and Seltzer and Mahmoudi (2012) claimed that data production by individuals could be voluntary or involuntary.

Despite the varied definitions that can be found in the literature, there is a consensus related to the presence of returns for this participation, and that meet motivational factors such as love, money, glory, socialization or altruism (MALONE; LAUBACHER; DELLAROCAS， 2010; ZHENG; LI; HOU, 2014; SOLIMAN; TUUNAINEN, 2014; ZHAO; ZHU, 2014; CUPID; OPHOFF, 2014; AITAMURTO, 2015; ZOLKEPLI; HASNO; MUKHIAR, 2015; SUKAINI et al., 2015). Thus, crowdsourcing is an activity performed by individuals or groups of individuals in various ways that would bring the participant a return, financial or otherwise.

By analyzing the cases presented in this paper (Netflix, Facebook, and Google), it was found that all are cited in different articles, or by the platforms themselves, as examples of crowdsourcing, regardless of the type of activity performed by individuals. In the case of Netflix and Google Maps, the type of crowdsourcing called crowdevaluation (SIVULA; KANTOLA, 2015) is mentioned. In the case of developing an algorithm for Netflix through an open call, Majchrzak and Malhotra (2013) and Nakatsu, Grossman, and Iacovou (2014) categorize this crowdsourcing as a challenge and Schenk and Guittard (2011) as complex tasks. There are still authors who name the search activity performed through Google as a microtask (SIVULA; KANTOLA, 2015; GOOD; SU, 2015). Crowdsourcing content development or open collaboration is also used as a category for actions taken by users of the social network Facebook (HOSSAIN; KAURANEN, 2015; PRPIC, TAEIHAGH; MELTON, 2015).

By exploring the activities performed and how they are performed by individuals, as well as the return they receive, it was found that the organizations themselves present their business models and digital platforms as altruistic poles with little commercial interest. The policies of these organizations were also found to be presented in the background or on secondary pages with regard to the operational forms in which user data are explored and expropriated.

In a study on the privacy policies of ICT organizations, Kumar (2017) stated that their privacy policies are aimed at monetizing, exploiting and passing on information for better advertising. Such privacy policies usually link the operation and full use of the 
platform to the user's acceptance of the platform and also authorizes the platform to set tracking cookies on the user's device.

In the case of the Netflix organization, the platform itself, on its home page, calls itself an innovation in the service of streaming movies and series online. The platform information page shows the benefits offered to its customers, such as its evaluation system. The company's policy regarding the use of subscriber data is located on a secondary page, informing that user data can be used in a variety of ways for whatever purpose the organization desires.

From simply viewing a trailer to a delay in choosing a movie, actions are turned into data that serve as the basis for testing Netflix does with its users without their active consent. The performance of users in this type of collective intelligence activity is much closer to the function of sensors that respond to Netflix stimuli than to the activity of summoned and motivated collaborators.

In the case of the Facebook organization, not charging its users for participation can give the impression that their intention is to bring people together and empower them. However, as demonstrated, its structure of avatars that produce content that is evaluated, analyzed and manipulated by the platform to satisfy its political and financial objectives, makes the business obscure.

In its policies, Facebook has different ways of using and exploiting usergenerated data at any rate. Data generated by the attention of seconds given to a piece of news is already data that can be quantified, classified and used later to draw the user's attention. The user becomes a sensor without any noticeable summons or compensation.

Google organization information presents users organizers of information that is accessible and useful to everyone. From a functionalist perspective, Google helps its users through surveys, maps and other structures for free. However, by analyzing the data and information about the platform, as well as its policies and other previous research, it can be said that Google's concern is solely focused on generating financial results through advertisements.

Practices such as categorizing users based on their search data to determine which future search results will result in profitable hits for their customer and the platform itself are pushed to the extreme. The exploitation of data and users from their reactions to the results presented by the platform itself makes these users important pieces in the platform's digital system. However, this importance is evidenced in a 
function close to that of sensors and distant from the characteristic empowerment of romantic crowdsourcing.

\section{DISCUSSION AND CONCLUSION}

The cases analyzed in the present study show that there is a possibility that individuals, at some point in the development of Information and Communication Technologies, have been seen as human beings who could use the activities available on the web to achieve individual, emotional, professional and social goals or help organizations to pursue their goals in a win-win operation. However, currently, they are not. The notion of crowdsourcing as a search for solutions or innovations in broad groups of individuals empowered by web 2.0 (SCHENK; GUITTARD, 2011; PENIN; BURGER-HELMCHEN, 2011; O’REILLY, 2006) was quickly discarded (ZUBOFF, 2019).

The idea presented in the crowdsourcing account of the eighteenth-century British government challenge that relied on an outsider motivated to solve a problem or propose an innovation for recognition and money (AFFUAH; TUCCI, 2012) has been replaced in the digital age by a fixed idea of profit (ZUBOFF, 2019). Such ideological substitution occurs when organizations come to realize that the use of Information and Communication Technologies could create more efficient systems with data storage and crossover capabilities (LIN et al., 2018; PILLONI, 2018). At this time, an obscure era in the relationships between these organizations and individuals has begun to be drawn (PASQUALE, 2016).

At the end of the theoretical framework on crowdsourcing and crowdsensing, questions were asked that sought to highlight possible advances in the theories covered. As for the advances in studies on crowdsourcing in the light of a critical perspective, it is possible to state that the term crowdsourcing may no longer be appropriate for activities that do not involve the conscious action of individuals. It would then be more appropriate to use the term crowdsensing, since the individual's lack of knowledge about the use of their data, or even the misconduct that results in misinformation about this use of data, removes the voluntariness present in the initial terms of crowdsourcing.

As for studies on crowdsensing, the theoretical and empirical advances were presented through the analysis of the cases of this study, which show a moment when there is no longer a need for individuals to volunteer their perceptions with 
organizations or platforms, as this will occur anyway. The perception of individuals as sensors is dangerous, as it puts people inside a computer system that can do anything since sensors are its parts. Therefore, this could be the time for individuals and those who must protect their interests through appropriate policies to pay attention to these unequal relationships and which widen the inequalities between groups that hold power and those who are subordinate (EUBANKS, 2018).

This obscurantism has been referred to using names such as Industry 4.0 and Big Data and its use has been widespread since 2012 by the term 4.0 (YIN; STECKE; LIN, 2017) and all the derivatives of these names. All the terms share a direct relationship with data capture (PILLONI, 2018), not users or clients. Thus, Pasquale (2016), MayerSchönberger and Cukier (2013) and Couldry and Mejias (2019) warned of the unidimensionality present in world 4.0 processes, which seek to meet the neoliberal interests of organizations that guide their business models by way of the surveillance capitalism concept. Zuboff (2019, p. 42) stated that surveillance capitalism could be identified as a new generation of economic power that results from the transformation of data from casual research and clicks into an "asset to be tracked, analyzed and monetized".

Thus, it can be said that data is the essence, the raw material, or the oil of the 4.0 era (DAWID et al., 2017; WEF, 2019; ZUBOFF, 2019), even if different names are assigned to the black boxes in which they are analyzed and processed, such as IoT (PILLONI, 2018), smart manufacturing (QIN et al., 2016; MALACUKZI, 2017) and Big Data (YAO; LIN, 2015; PILLONI, 2018; YANG; CHENG; WANG, 2018 ). In this way, the expropriation of the data generated by individuals occurs, in surveillance capitalism, as the exploitation of any other input by capital, in the most creative (and perverse) ways possible, and even its exhaustion (O’NEIL, 2016).

In surveillance capitalism, the data come from a behavioral or individual behavioral surplus (ZUBOFF, 2019) and are later processed, analyzed and categorized by algorithms. These algorithms, or black boxes (PASQUALE, 2015), cross sensations, emotions, and intimacies are based on the priorities of organizations, but in ways that even the organization itself is not fully aware (PASQUALE, 2015).

The present study was developed using the case study method, due to the possibility that this method presents of structuring a discussion about a phenomenon that still needs defining within the context in which it presents itself. To present such a structure, the following questions were asked: how do individuals participate in digital 
platforms from the concepts of crowdsourcing and crowdsensing?; how are these interests made possible through their terms of service?; and why do the studied digital platforms need these participations to take ownership of user data and make their business viable? To apply the method, the content of the platforms themselves, their privacy policies and terms of service, and secondary articles were analyzed.

Thus, it was possible to evidence, based on the functioning of organizations like Google, Facebook, and Netflix, and their policies, that the goal of surveillance capitalism organizations is to expropriate data from movements with remote controls or movements of the mobile device. While the platform homepages present them as enabling better but more sociable and knowledgeable lives, the policies and terms of service, hidden on secondary pages, show the opposite. These privacy policies and terms of service indicate that cookies are installed on devices to monitor users' steps, and that data may be shared with third parties and partners. The same policies and terms of service further describe that full use of the platforms will only occur if these terms are accepted.

By presenting how these organizations' digital platforms rely on user participation, it is clear why this participation is not related to a concern with user empowerment or improving any aspect of their life. User participation is related to greater access to the data they produce, whether consciously or not. This operationalization of systems removes the romantic and co-creationist perspective of the user, characteristic of authors such as Howe (2006), and results in the perception of the user as a machine connected to sensors (CONTI; PASSARELLA; DAS , 2017; DAWID et al., 2017).

Therefore, it can be said that the expropriation of organizations operating in surveillance capitalism-based business models is masked by the concept of empowering the notion of crowdsourcing, and its privacy and cookie policies. This masking of the real intentions and actions of surveillance capitalism organizations can also affect social policies, widening inequalities, and take advantage of the suffering of individuals (O’NEIL, 2016; EUBANKS, 2018).t An example of the consequences arising from the distortions of vigilant capitalism is the situation reported by O'Neil (2016), where the author describes cases in which users' Google searches on emotional difficulties were used to categorize users themselves as "weak". Along with categorization, the platform now offers products and services more easily purchased by vulnerable individuals. Eubanks (2018) also reported how the operation of Big Data-based platforms and 
crowdsourcing-based automated systems drive vulnerable individuals away from access to social policies. To a large extent, this is because the systems are unable to identify the demands and specificities of individuals, only being able to quantify them according to the algorithm's priority.

The conclusions of this study also help to broaden the possibilities of studies on the dark side of organizations, especially the dark side of digitization. This is because this study presents how digital organizations structure themselves with the state and take advantage of their stronger condition with regard to users to develop processes and policies that exclusively suit their pursuit of financial results and the expansion of power. Finally, the study sought to broaden the scope of organizational studies and contribute to the structuring of research on the dark side of digitization.

\section{REFERENCES}

ABRAMOWICZ, W.; AUER, S.; HEATH, T. Linked Data in Business. Business \& Information Systems Engineering, v. 5, n. 58, p. 323-326, 2016.

AL SUKAINI, A. K. M.; ZHANG, J.; ALBAZOONI, A. G. Z. Mobile crowdsourcing: Intrinsic and extrinsic motivational factors influencing online communities in China. Journal of Marketing Development and Competitiveness, v. 9, n. 1, p. 129, 2015.

AFUAH, A.; TUCCI, C. L. Value capture and crowdsourcing. Academy of Management Review, v. 38, n. 3, p. 457-460, 2013.

AITAMURTO, T. Motivation factors in crowdsourced journalism: Social impact, social change, and peer learning. Social Change, and Peer Learning: International Journal of Communication, v. 9, p. 3523-3543, 2015.

AHLSKOG, M.; BRUCH, J.; JACKSON, M. Knowledge integration in manufacturing technology development. Journal of Manufacturing Technology Management, v. 28, n. 8, p. 1035-1054, 2017.

ALTAWEEL, I.; GOOD, N.; HOOFNAGLE, C. J. Web privacy census. Technology Science, v. 2015121502, p. 1-28, 2015.

ANTHUAN, T.; SHOAIB, H.; JOOYOUNG, P. Crowd participation pattern in the phases of a product development process that utilizes crowdsourcing. Industrial Engineering and Management Systems, v. 11, n. 3, p. 266-275, 2012.

BARRETO, T. F.; BACELAR, D. F.; DE ARAUJO, M. H. C. C.; FEITOSA, M. G. G.; LÔRETO, M. S. S. "Soltem os beagles": desvelando o dark side das organizações a partir da perspectiva da ética animal. Revista Brasileira de Estudos Organizacionais, v. 4, n. 1, p. 319, 2017.

BAUMANN, F.; ROLLER, D. Additive manufacturing, cloud-based 3D printing and associated services - overview. Journal of Manufacturing and Materials Processing, v. 1, n. 2, p. 15, 2017. 
BELL, R. M.; KOREN, Y. Lessons from the Netflix prize challenge. SiGKDD Explorations, v. 9, n. 2, p. 75-79, 2007.

BENKLER, Y. From consumers to users: Shifting the deeper structures of regulation toward sustainable commons and user access. Fed. Comm. LJ, v. 52, p. 561, 1999.

BERTHON, P. R.; PITT, L. F.; PLANGGER, K.; SHAPIRO, D. Marketing meets Web 2.0, social media, and creative consumers: Implications for international marketing strategy. Business horizons, v. 55, n. 3, p. 261-271, 2012.

BLOHM, I.; LEIMEISTER, J. M.; KRCMAR, H. Crowdsourcing: how to benefit from (too) many great ideas. MIS Quarterly Executive, v. 12, n. 4, p. 199-211, 2013.

BRETSCHNEIDER, U.; LEIMEISTER, J. M.; MATHIASSEN, L. IT-enabled product innovation: Customer motivation for participating in virtual idea communities. Int. J. Product Development, v. 20, n. 2, p. 126-141, 2015.

BURMEISTER, C.; LÜTTGENS, D.; PILLER, Frank T. Business model innovation for Industrie 4.0: why the "Industrial Internet" mandates a new perspective on innovation. Die Unternehmung, v. 70, n. 2, p. 124-152, 2016.

CAGGIANO, A. Cloud-based manufacturing process monitoring for smart diagnosis services. International Journal of Computer Integrated Manufacturing, v. 31, n. 7, p. 612-623, 2018.

CHARITSIS, V.; ZWICK, D.; BRADSHAW, A. Creating Worlds that Create Audiences: Theorising Personal Data Markets in the Age of Communicative Capitalism. tripleC: Communication, Capitalism \& Critique. Open Access Journal for a Global Sustainable Information Society, v. 16, n. 2, p. 820-834, 2018.

COLEMAN, D. J.; GEORGIADOU, Y.; LABONTE, J. Volunteered geographic information: the nature and motivation of producers. International Journal of Spatial Data Infrastructures Research, v. 4, p. 332-358, 2009.

CONTI, M.; PASSARELLA, A.; DAS, S. K. The Internet of People (IoP): A new wave in pervasive mobile computing. Pervasive and Mobile Computing, v. 41, p. 1-27, 2017.

COOPER, R.; BURRELL, G. Modernism, postmodernism and organizational analysis: An introduction. Organization Studies, v. 9, n. 1, p. 91-112, 1988.

COULDRY, N. Surveillance-democracy. Journal of Information Technology \& Politics, v. 14, n. 2, p. 182-188, 2017.

COULDRY, N.; MEJÍAS, U. A. The costs of connection: How data is colonizing human life and appropriating it for capitalism. Stanford University Press, 2019.

COULDRY, N.; YU, J. Deconstructing datafication's brave new world. New Media \& Society, v. 20, n. 12, p. 4473-4491, 2018.

CUPIDO, K.; OPHOFF, J. A model of fundamental components for an e-government crowdsourcing platform. Electronic Journal of e-Government, v. 12, n. 2, p. 142, 2014.

DAWID, H.; DECKER, R.; HERMANN, T.; JAHNKE, K; KLAT, W.; KONIG, R.; STUMMER, C. Management science in the era of smart consumer products: challenges and research perspectives. Central European Journal of Operations Research, v. 25, n. 1, p. 203-230, 2017. 
DE OLIVEIRA MEDEIROS, C. R.; ALCAPADIPANI, R. In the corporate backstage, the taste of revenge: Misbehaviour and humor as form of resistance and subversion. Revista de Administração, v. 51, n. 2, p. 123-136, 2016.

DING, K.; JIANG, P.; SU, S. RFID-enabled social manufacturing system for interenterprise monitoring and dispatching of integrated production and transportation tasks. Robotics and Computer-Integrated Manufacturing, v. 49, p. 120-133, 2018.

EL KALIOUBY, R.; PICARD, R.; BARON- COHEN, S. Affective computing and autism. Annals of the New York Academy of Sciences, v. 1093, n. 1, p. 228-248, 2006.

ETTLINGER, N. The governance of crowdsourcing: Rationalities of the new exploitation. Environment and Planning A: Economy and Space, v. 48, n. 11, p. 2162-2180, 2016.

EUBANKS, V. Automating inequality: How high-tech tools profile, police, and punish the poor. St. Martin's Press, 2018.

FABER, A.; MATTHES, F. Crowdsourcing and crowdinnovation. Digital Mobility Platforms and Ecosystems, p. 36-48, 2016.

FACEBOOK. Privacy. Avaible in: https://www.facebook.com/msqrd/privacy. Accessed in: 2019/02/01.

FOSTER, J. B.; MCCHESNEY, R. W. Surveillance capitalism: Monopoly-finance capital, the military-industrial complex, and the digital age. Monthly Review, v. 66, n. 3, p. 1, 2014.

FUCHS, C. Web 2.0, prosumption, and surveillance. Surveillance \& Society, v. 8, n. 3, p. 288-309, 2011.

GAO, R.; WANG, L.; TETI, R.; DORNEFELD, D.; KUMARA, S.; MORI, M.; HELU, M. Cloud-enabled prognosis for manufacturing. CIRP annals, v. 64, n. 2, p. 749-772, 2015.

GOMEZ-URIBE, C. A.; HUNT, N. The netflix recommender system: Algorithms, business value, and innovation. ACM Transactions on Management Information Systems (TMIS), v. 6, n. 4, p. 13, 2016.

GOOD, B. M.; SU, A. I. Crowdsourcing for bioinformatics. Bioinformatics, v. 29, n. 16, p. 1925-1933, 2013.

GOOGLE. About Google. Avaible in: https://about.google/intl/ptBR_br/?utm_source=google-BR\&utm_medium=referral\&utm_campaign=hpfooter $\& f g=1$ Accessed in: 2019/03/01

HALLINAN, B.; STRIPHAS, T. Recommended for you: The Netflix Prize and the production of algorithmic culture. New media \& society, v. 18, n. 1, p. 117-137, 2016.

HASSAN, T; GAO, F.; JALAL, B.; ARIF, S.. Interference management in femtocells by the adaptive network sensing power control technique. Future Internet, v. 10, n. 3, p. 25, 2018.

HELLER, A.; FEHER, F. The postmodern political condition. Cambridge: Polity Press, 1988.

HOSSAIN, M.; KAURANEN, I. Crowdsourcing: a comprehensive literature review. Strategic Outsourcing: An International Journal, v. 8, n. 1, p. 2-22, 2015. 
HOSSEINI, M.; SHAHRI, A.; PHALP, K.; TAYLOR, J.; ALI, R. Crowdsourcing: A taxonomy and systematic mapping study. Computer Science Review, v. 17, p. 43-69, 2015.

HOWE, J. The rise of crowdsourcing. Wired magazine, v. 14, n. 6, p. 1-4, 2006.

JACKSON, S. J. (Re) imagining intersectional democracy from Black feminism to hashtag activism. Women's Studies in Communication, v. 39, n. 4, p. 375-379, 2016.

KHASRAGHI, H. J.; TAROKH, M. J. Efficient business process reengineering with crowdsourcing. International Journal of Applied Information Systems, v. 2, n. 7, 2012.

KIDD, C. D.; OOR, R.; ABOWD, G. D.; ATKESON, C. G.; ESSA, I. A.; MASINTIRE, B.; NEWSTETTER, W. The aware home: A living laboratory for ubiquitous computing research. In: International Workshop on Cooperative Buildings. Springer, Berlin, Heidelberg, 1999. p. 191-198.

KUMAR, P. Corporate Privacy Policy Changes during PRISM and the Rise of Surveillance Capitalism. Media And Communication, v. 5, n. 1, p. 63, 2017.

LAUBACHER, R. J. Entrepreneurship and venture capital in the age of collective intelligence. Chance and intent-Managing the risks of innovation and entrepreneurship. London, UK: Routledge. Section, v. 8, 2012.

LEE, J.; BAGHERI, B.; JIN, C.. Introduction to cyber manufacturing. Manufacturing Letters, v. 8, p. 11-15, 2016.

LEHTINIEMI, T. Personal Data Spaces: An Intervention in Surveillance Capitalism?. Surveillance \& Society, v. 15, n. 5, p. 626-639, 2017.

LI, Z.; WANG, W. M.; LIU, G.; LIU, L.; HE, J.; HUANG, G. Q. Toward open manufacturing: A cross-enterprises knowledge and services exchange framework based on blockchain and edge computing. Industrial Management \& Data Systems, v. 118, n. 1, p. 303-320, 2018.

LIN, D.; LEE, C. K. M.; LAU, H.; YANG, Y. Strategic response to Industry 4.0: an empirical investigation on the Chinese automotive industry. Industrial Management \& Data Systems, v. 118, n. 3, p. 589-605, 2018.

LINDOO, E. Using google sites, google groups and google documents to enhance your course. Journal of Computing Sciences in Colleges, v. 25, n. 2, p. 46-51, 2009.

LINSTEAD, S.; MARÉCHAL, G.; GRIFFIN, R. W. Theorizing and researching the dark side of organization. Organization Studies, v. 35, n. 2, p. 165-188, 2014.

MAJCHRZAK, A.; MALHOTRA, A. Towards an information systems perspective and research agenda on crowdsourcing for innovation. The Journal of Strategic Information Systems, v. 22, n. 4, p. 257-268, 2013.

MALAKUCZI, V. Raising new opportunities for the Next Economy by exploring variable user needs for Computational Co-Design. The Design Journal, v. 20, n. sup1, p. S581-S588, 2017.

MALONE, T. W.; LAUBACHER, R.; DELLAROCAS, C. The collective intelligence genome. MIT Sloan Management Review, v. 51, n. 3, p. 21, 2010.

MAYER-SCHÖNBERGER, V.; CUKIER, K. Big data: A revolution that will transform how we live, work, and think. Houghton Mifflin Harcourt, 2013.

McLUHAN, M.; NEVITT, B. Take today: the executive as dropout. Don Mills, 1972. 
MOREL M.; ALVES, M.; CADET, P. Google apps: Mastering integration and customization. Packt Publishing Ltd., 2011.

MOROZOV, E. Big Tech: a ascensão dos dados e a morte da política. Tradução de Claudio Marcondes. São Paulo: Ubu Editora, 2008.

MORRAR, R.; ARMAN, H.; MOUSA, S. The fourth industrial revolution (Industry 4.0): A social innovation perspective. Technology Innovation Management Review, v. 7, n. 11, p. 12-20, 2017.

NAKATSU, R. T.; GROSSMAN, E. B.; IACOVOU, C. L. A taxonomy of crowdsourcing based on task complexity. Journal of Information Science, v. 40, n. 6, p. 823-834, 2014.

NETFLIX. Terms of use. Avaible on: <https://help.netflix.com/legal/termsofuse> Accessed in 2019/02/08.

OBAR, J. A.; OELDORF-HIRSCH, A. The biggest lie on the internet: Ignoring the privacy policies and terms of service policies of social networking services. Information, Communication \& Society, p. 1-20, 2018.

O'NEIL, C. Weapons of math destruction: How big data increases inequality and threatens democracy. Broadway Books, 2016.

O'REILLY, T. What is Web 2.0: Design patterns and business models for the next generation of software. Communications \& strategies, n. 1, p. 17, 2007.

ORGANIZATION. Exploring dark and unexpected sides of digitalization: How digital technologies challenge organization and organizing. Call for papers: Special Issue of Organization, p. 1-5, 2019. Avaible in: https://journals.sagepub.com/pbassets/ORG\%20Call\%20for\%20Papers.pdf

PAPANASTASIOU, Y.; BIMPIKIS, K.; SAVVA, N. Crowdsourcing exploration. Management Science, v. 64, n. 4, p. 1727-1746, 2017.

PASQUALE, F. The black box society. Harvard University Press, 2015.

PCLOB - PRIVACY AND CIVIL LIBERTIES OVERSIGHT BOARD. Report on the surveillance program operated pursuant to section $\mathbf{7 0 2}$ for foreign intelligence surveillance act. 2014.

PENIN, J.; BURGER-HELMCHEN, T. Crowdsourcing of inventive activities: definition and limits. International Journal of Innovation and Sustainable Development, v. 5, n. 2, p. 246, 2011.

PILLONI, V. How data will transform industrial processes: Crowdsensing, crowdsourcing and big data as pillars of Industry 4.0. Future Internet, v. 10, n. 3, p. 24, 2018.

PONSONBY, A.; MATTINGLY, K. Evaluating new ways of working collectively in science with a focus on crowdsourcing. EBioMedicine, v. 2, n. 7, p. 627-628, 2015.

PRPIĆ, J.; TAEIHAGH, A.; MELTON, J. The fundamentals of policy crowdsourcing. Policy \& Internet, v. 7, n. 3, p. 340-361, 2015.

QIN, S.; VAN DER VELDE, D.; CHATZAKIS, E.; MCSTEA, T.; SMITH, N. Exploring barriers and opportunities in adopting crowdsourcing based new product development in manufacturing SMEs. Chinese Journal of Mechanical Engineering, v. 29, n. 6 , p. 1052-1066, 2016. 
RITZER, G.; JURGENSON, N. Production, consumption, prosumption: The nature of capitalism in the age of the digital 'prosumer'. Journal of consumer culture, v. 10, n. 1, p. 13-36, 2010.

SALLOUM, S. A.; AL-EMRAN, M.; SHAALAN, K. Mining text in news channels: a case study from Facebook. International Journal of Information Technology and Language Studies, v. 1, n. 1, p. 1-9, 2017.

SAXTON, G. D.; OH, O.; KISHORE, R. Rules of crowdsourcing: Models, issues, and systems of control. Information Systems Management, v. 30, n. 1, p. 2-20, 2013.

SCHENK, E.; GUITTARD, C. Towards a characterization of crowdsourcing practices. Journal of Innovation Economics Management, n. 1, p. 93-107, 2011.

SCHUURMAN, D.; BACCARNE, B.; DE MAREZ, L.; MECHANT, P. Smart ideas for smart cities: investigating crowdsourcing for generating and selecting ideas for ICT innovation in a city context. Journal of theoretical and applied electronic commerce research, v. 7, n. 3, p. 49-62, 2012.

SELTZER, E.; MAHMOUDI, D. Citizen participation, open innovation, and crowdsourcing: Challenges and opportunities for planning. Journal of Planning Literature, v. 28, n. 1, p. 3-18, 2013.

SHADE, L. R.; SINGH, R. "Honestly, We're Not Spying on Kids": School Surveillance of Young People's Social Media. Social Media+ Society, v. 2, n. 4, p. $2056305116680005,2016$.

SHILTON, K. Participatory sensing: Building empowering surveillance. Surveillance \& Society, v. 8, n. 2, p. 131-150, 2010.

SHU, L.; CHEN, Y.; HUO, Z.; BERGMANN, N.; WANG, L. When mobile crowd sensing meets traditional industry. IEEE Access, v. 5, p. 15300-15307, 2017.

SILVEIRA, R. A. da; MEDEIROS, C. R. O. Viver e morrer pelo trabalho: uma análise da banalidade do mal nos crimes corporativos. Organizações \& Sociedade, v. 21, n. 69, p. 217-234, 2014.

SILVERMAN, Jacob. Privacy under Surveillance Capitalism. Social Research: An International Quarterly, v. 84, n. 1, p. 147-164, 2017.

SIVULA, A.; KANTOLA, J. Integrating crowdsourcing with holistic innovation management. International Journal of Advanced Logistics, v. 5, n. 3-4, p. 153-164, 2016.

SOLIMAN, W.; TUUNAINEN, V. K. Understanding continued use of crowdsourcing systems: An interpretive study. Journal of theoretical and applied electronic commerce research, v. 10, n. 1, p. 1-18, 2015.

SONG, Z.; MOON, Y. Assessing sustainability benefits of cybermanufacturing systems. The International Journal of Advanced Manufacturing Technology, v. 90, n. 5-8, p. 1365-1382, 2017.

THE SOCIAL NETWORK. David Fincher. United States of America: Columbia Pictures. 2010.

TOFFLER, A. The third wave: The classic study of tomorrow. New York: Bantam, 1984. 
TRAN, T.; PARK, J. Y. A quantitative study of influencing factors on crowd participation in a crowdsourcing project for consumer product design. Industrial Engineering \& Management Systems, v. 14, n. 4, p. 325-334, 2015.

TREDINNICK, L. Web 2.0 and Business: A pointer to the intranets of the future?. Business information review, v. 23, n. 4, p. 228-234, 2006.

TURNER, F. The arts at Facebook: An aesthetic infrastructure for surveillance capitalism. Poetics, v. 67, p. 53-62, 2018.

UPCHURCH, M.; GRASSMAN, R. Striking with social media: The contested (online) terrain of workplace conflict. Organization, v. 23, n. 5, p. 639-656, 2016.

VALERIO, L.; PASSARELLA, A.; CONTI, M. A communication efficient distributed learning framework for smart environments. Pervasive and Mobile Computing, v. 41, p. 46-68, 2017.

VARIAN, H. R. Beyond big data. Business Economics, v. 49, n. 1, p. 27-31, 2014.

VASANTHA, A.; VIJAYUMAR, G.; CORNEY, J.; ACUR BAKIR, N.; LYNN, A.; JAGADEESAN, A. P.; AGARWAL, A. Social implications of crowdsourcing in rural scotland. International Journal of Social Science \& Human Behavior Study, v. 1, n. 3, p. 47-52, 2014.

VENTURINI, J.; LOUZADA, L.; MACIEL, M.; ZINGALES, N.; ATYLIANOU, K.; BELLI, L. Terms of servisse and human rights: An analysis of online platforms contracts. Rio de Janeiro, Brasil: Editora Revan, 2016.

YANG, C.; SHEN, W.; WANG, X. The internet of things in manufacturing: Key issues and potential applications. IEEE Systems, Man, and Cybernetics Magazine, v. 4, n. 1, p. 6-15, 2018.

YAO, X.; LIN, Y. Emerging manufacturing paradigm shifts for the incoming industrial revolution. The International Journal of Advanced Manufacturing Technology, v. 85, n. 5-8, p. 1665-1676, 2016.

YAO, X.; ZHOU, J.; LIN, Y.; LI, Y.; YU, H.; LIU, Y. Smart manufacturing based on cyber-physical systems and beyond. Journal of Intelligent Manufacturing, p. 1-13, 2017.

YIN, Y.; STECKE, K. E.; LI, D. The evolution of production systems from Industry 2.0 through Industry 4.0. International Journal of Production Research, v. 56, n. 1-2, p. 848-861, 2018.

YIN, R. K. Case study research and applications: Design and methods. Sage publications, 2017.

WEF - World Economic Forum. Data science in the new economy: A new race for talent in the Fourth Industrial Revolution. Insight Report, p. 1-22, 2019. Avaible in: http://www3.weforum.org/docs/WEF_Data_Science_In_the_New_Economy.pdf

WIENER, N. The human use of human beings: Cybernetics and society. n. 320. Perseus Books Group, 1988.

WILLIAMS, C. B.; GULATI, G. J. Social networks in political campaigns: Facebook and the congressional elections of 2006 and 2008. New Media \& Society, v. 15, n. 1, p. 52-71, 2013.

ZEINAB, K. A. M.; ELMUSTAFA, S. A. A. Internet of Things applications, challenges and related future technologies. World Scientific News, v. 2, n. 67, p. 126-148, 2017. 
ZHANG, W.; YANG, Y.; ZHANG, S.; YU, D.; LI, Y. Correlation-aware manufacturing service composition model using an extended flower pollination algorithm. International Journal of Production Research, v. 56, n. 14, p. 4676-4691, 2018.

ZHAO, Y.; ZHU, Q. Effects of extrinsic and intrinsic motivation on participation in crowdsourcing contest: A perspective of self-determination theory. Online Information Review, v. 38, n. 7, p. 896-917, 2014.

ZHENG, H.; LI, D.; HOU, W. Task design, motivation, and participation in crowdsourcing contests. International Journal of Electronic Commerce, v. 15, n. 4, p. 57-88, 2011.

ZOGAJ, S.; BRETSCHNEIDER, U.; LEIMEISTER, J. M. Managing crowdsourced software testing: a case study based insight on the challenges of a crowdsourcing intermediary. Journal of Business Economics, v. 84, n. 3, p. 375-405, 2014.

ZOLKEPLI, I. A.; HASNO, H.; MUKHIAR, S.; NADIAH, S. Online Social Network Citizen Engagement on Instagram Crowdsourcing: A Conceptual Framework. Electronic Journal of Knowledge Management, v. 13, n. 4, 2015.

ZOOK, M.; GRAHAM, M.; SHELTON, T.; GORMAN, S. Volunteered geographic information and crowdsourcing disaster relief: a case study of the Haitian earthquake. World Medical \& Health Policy, v. 2, n. 2, p. 7-33, 2010.

ZUBOFF, S. Big other: surveillance capitalism and the prospects of an information civilization. Journal of Information Technology, v. 30, n. 1, p. 75-89, 2015.

ZUBOFF, Shoshana. The age of surveillance capitalism: The fight for a human future at the new frontier of power. Profile Books, 2019. 